\title{
MASS PRIVATIZATION AND ECONOMIC REFORM IN NORTH KOREA: TOWARDS A HARD STATE APPROACH
}

\author{
Junki Kim*
}

\begin{abstract}
As seen in Eastern European nations and former Soviet Union, mass privatization is an intense political process that requires strong leadership from the top as well as bottom-up political support from workers, managers, and the population at large. Given that North Korea's productivity is likely to be in less than that of other former socialist nations, simultaneous restructuring and reform programs are essential. This makes mass privatization all the more critical. The primary goal of mass privatization plan should be to create well-functioning market economy, which is best achieved by selling off SOEs as quickly as possible. Other economic and social concerns should not detract the government. In sum, it is important to establish an economic reform agenda early; otherwise, the window of opportunity available in reforming transition economies might be lost, which will only make the reform process much harder to implement in future date.
\end{abstract}

\section{INTRODUCTION}

\section{Despite South Korea's (SK's) conciliatory} approach ${ }^{1)}$ to the Northern regime, and the resulting flow of capital and goods, North Korea (NK) is showing little signs of economic recovery. NK, which experienced severe economic downturns since the late 1980 's, is at a point where important policy decisions concerning its economic future need to be made. One such decision is the mechanics of restructuring and privatizing NK's state-owned enterprise (SOE) sector. As witnessed in the East European nations and former Sovict Union (EEFSU), the question is whether 'the big bang (shock therapy)' or 'gradual' approach (Berg and Sachs, 1994; Blanchard et al., 1992, Fisher, 1993; Frydman et al., 1990; Kim, 1997; and Sachs and Woo, 1995) towards privatization should be employed.

\footnotetext{
* Professor, Graduate School of Public Administration, Seoul National University.

1) It is also known as 'sunshine' policy in the South.
}

Although these two terms have been used somcwhat loosely in the literature, the 'big bang' approach is an expedient divestiture of SOEs, while simultaneously implementing other structural adjustment policies like macroeconomic stabilization and control, price and market reform, private sector development and enterprise restructuring, and redefining the economic role of the state. This allows parties and individuals involved in the process to realign their objective functions and there by paving ways for 'fundamental changes' in the way government and market interact. The 'gradual' approach, on the other hand, refers to a more 'controlled' transition process, including the privatization of SOEs. Proponents of the laller approach argue that slower economic reform programs will foster a smoother transition into a market-based economy and reduce the socio-economic contractions of output and employment associated with the former approach. The debate, thus, concerns what role the State should take, specifically with respect to NK's SOE sector, when transforming this highly 
centralized economy.

The debate is even more critical in an economy where the state-sector's contribution to the national GNP increased to 70\% in 1993 (Bank of Korea, 1994), making it one of the most centralized economies in the world. In addition, the SOE scctor is reportedly in far worse shape than most other transition economies due to its economic rigiditythat is, having a highly bureaucratic economic structure (Kim, 1996)- and its commitment to Juche ideology.2) (Kang and Lee, 1993). Reforming SOEs is critical for a comprehensive structural adjustment program to overcome the pervasive problem of a centralized command economy, namely over-hoarding and inefficient allocation of scarce resources. (Gray and Gelb, 1991). I have argued in a previous paper (Kim, 1997) that economic reform in NK requires a more radical approach due to its highly industrialized economic structure and past failures at gradual reform attempts. The same line of thinking will be used when examining the issues concerning mass privatization of NK's SOE sector.

The primary objective of a mass privatization program (MPP) is to privatize SOEs as quickly as possible in order to create stable market infrastructures and institutions. According to Lieberman (1995), "given the political constraints facing policy makers in numerous socialist nations, such as little private capital formation, a political limit on the sale of SOEs to foreign investors, a need to involve and commit the population at large to the process of economic transformation, and a social need to weak equity through wide-distributed ownership, mass privatization programs have been highly attractive and successful in accomplishing this goal." Confronted with severe financial drains by SOEs, EEFSU economies privatize much of their economy to radically alter the relationship

2) A term loosely translated as 'self-reliant' ideology, a view which has basically isolated NK from the rest of the world. between SOEs and the state. They sought to 'depoliticize' ownership and other control process in 25,000 large SOEs in Russia, 8,500 in Poland, 6,000 in Czech and Slovak Republics, and 2,400 in Lithuania through the MPPs.

Similarly, the long-term objective of NK is to move to a more capitalist economy through its political-economic union with the South. ${ }^{3)}$ This is because capitalism is considered to be the best means to achieve economic efficiency (Kornai, 1994; Tirole, 1991). Since a discussion of the various economic systems with respect to their productive and allocative efficiency is beyond the scope of this paper, let us take the efficiency of capitalism as a given. As such, we will seek to analyze all that is involved when transitioning to a market-based economy, especially the privatization of NK's SOE sector. To that end, an examination of the theoretical issues arising from a MPP is required, along with an assessment of valuation, the corporate governance structure, the industrial structure, and the transformation process.

In this paper, we first examine the issues surrounding the conversion of the SOE sector in transition economies: 'the big bang' approach versus the 'gradualism' approach. Through a brief discussion of the Chinese and EEFSU reform experience, we examine the long-term repercussions of carrying out respective policies in $\mathrm{NK}$ and the impact of these policy options on the SOEs' soft budget constraints. We then analyze various features of the MPPs that were implemented in EEFSU economies and attempt to derive lessons for NK. More specifically, we examine the mechanics of mass privatization schemes and the ways to harden budget constraints-both economy-wide and SOE sector specific-through ownership transfers to the private sector. We also discuss specific approaches that should be taken to institutionalize the process:

3) There are many paths to a political union but given the current status of the Northern regime and its economy, it is likely that the German-type 'aborption' will occur. 
restitution, mass privatization, voucher scheme, and the involvement of NK's workers and management. This is followed by conclusions.

\section{'THE BIG BANG' VERSUS 'GRADUALISM'}

'The Big Bang' approach involves a mass privatization of SOEs in a relatively short period of time, regardless of size and industrial structure, while leaving the task of corporate restructuring to new owners. ${ }^{4)}$ Some argue that a slower privatization approach combined with corporate restructuring measures should be pursued in place of MPPs (Tirole, 1991; Kikeri et al., 1992). This approach includes cash and capital injections as well as changes in the corporate governance structure. Given the likelihood that NK's economy will face severe contractions in both production and unemployment during the structural adjustment process, some economists have also suggested a program for selective subsidization (Cho and Lee, 1995).

Privatization through liquidation (Blanchard, 1994) was by far the most popular form of divestiture among nations undergoing structural adjustments. After a certain percentage of voting shares is deposited to the state, management buyouts (MBOs) take place where ownership of the firm is turned over to the management and workers. The primary argument against MBOs is the increased likelihood of labor retrenchment under any form of government ownership and control, as described by Blanchard (1994) in Poland, Bocko, Shleifer and Vishny (1995) in Russia, Lieberman et al. (1995) in Poland, Lithuania, Russia and the former Czechoslovakia. These scholars found little evidence of restructuring and reorganization when the state continued to control SEOs, whether by choice or by political pressures. Continued government in-

4) Although these terms encompass a diverse policy area, we only concentrate on privatization issues in this paper. volvement meant that controlling SOEs was often reverted to workers and managers who valued job security. This essentially made corporate restructuring almost impossible, since it was politically difficult to ignore the demands placed by workers and managers for the continuation of state subsidies. A timely transformation of SOEs into a viable market institution in economies faced with government bankruptcy was, therefore, prevented (Saches and Woo, 1995). In addition, profit retention and sharing among managers were not based on merits but based on 'egalitarian' approaches. Thus, any attempt to tie corporate performance to workers' pay did not yield the intended results. This led to a belief that an external 'shock therapy' was the only way to induce serious SOE reform in transition economies. This was reinforced by Blasi (1987) who found little evidence of MBO's effectiveness since there were no economic or managerial incentive benefits associated with employee participation in management of firms. In addition, at a time when the state lacked resources to refurnish SOEs, MBOs introduced the problem of raising outside financing since no shares were being sold to outsiders.

Enforcing property rights has been an important issue of EEFSU reform. Drawing from the Russian case, for example, Earle and Estrin (1994) warned that "management-controlled employee ownership may represent a continuation of the vacuum in property rights characteristic of pre-reform period, because the formal transfer of ownership has not brought in its train mechanisms of corporate governance." This is precisely the reason why emphasizing managerial autonomy without a clear notion of managerial accountability in SOEs would lead to a corporate governance vacuum. More importantly, the likelihood of spontaneous privatization is said to be greater in SOEs without supervising ministries during the transition period. Gradual privatization processes lead to more severe information asymmetry problems as management withhold 
more and more managerial and financial information from ministries, and as government administrative systems gradually collapse.5) This calls for rapid privatization, not less (The Economist, September 21, 1991). Thus, it is easy to see why the current partial reform attempts in NK, similar to the previous partial attempts, are unlikely to improve macroeconomic conditions and the conditions in the SOE sector.

Empirical evidence also suggests that gradual economic reform programs are ineffective. Lopez-deSilanes (1995), in his study of the privatization experience in Mexico, found that "the speed of each privatization process substantially influences the net (privatization) prices: the longer it takes to put the company on the block, the more severe the deterioration in performance, and the lower the premium obtained." In addition, he found that all government-designed efficiency-oriented restructuring plans including debt absorption, investment, and performance improvement programs did not increase the net price. His empirical evidence points to a premium for restructuring measures that expedite the privatization process.

Other main arguments for a gradual privatization process relates to establishing market institutions, restructuring SOEs to avoid the adverse consequences of labor shedding, and maximizing sales proceeds. However, there are pre-requisites for taking a gradual approach. You need to have relatively high savings rates to afford gradualism in reforming economies, as evidenced in China where the rate was over $20 \%$ in the early 1990 's. In NK, however, the savings rate is likely to fall well short of that number, which makes it extremely difficult to maintain a slow transformation process. There is another reason, this time on macroeconomic grounds, to believe that a gradual privatization process in

5) The 50-year black out on economic information on NK will prolung the amount of time it requires for South Korea's administration to replace the communist system and to effectively control it.
NK is not possible: its economy is not stable and require a major surgery. Thus, the goal of the SOE sector reform in NK should be on the expeditious conversion of the sector into private hands thereby allowing the development of a viable competitive industrial structure, which is most likely to be in light industries, services industries and agricultural businesses.

\section{PRIVATIZATION MECHANICS AND NK's SOE SECTOR}

Since 1946, when all 1034 private enterprises (most of which were owned by the Japanese during the Occupation Period) were nationalized in 1946 (Lee, 1995), private ownership had been banned in NK. Kim (1996) describes the plight of NK's SOE sector, which was under the permanent overhang of demand and in chronic shortage of essential supplies-problems that further led to the hoarding of resources (Kang and Lee, 1993; and Kim, 1996). Although it is impossible to know precisely how inefficient SOEs were until months after their collapse, the chronic under- invested energy shortages [how about "chronic energy shortages?"] and technology autarky made it one of the most unproductive sectors in the world (Far Eastern Economic Review, 1993). In this section, we describe issues concerning the mass privatization of the SOE sector and how the government should handle the following key reform issues: privatization mechanics, restitution, compensation, voucher and corporate governance structures.

\section{Restitution and Compensation}

This section concerns properties that were nationalized by the NK regime since 1945 and what principle, whether restitution or compensation, should be used after the restoration of a democratic regime in NK. The relative advantage of each option is as follows: restitution emphasizes the importance of property rights in newly trans- 
forming economies while compensation expedites the process of privatization and spurs private sector development.6) Although the choice depends on the initial commitment one makes to protecting property rights, preference has been given to compensation rule to expedite the process. The need to expeditiously allow the development of private sectors led most economists to adopt the compensation approach.

Thus, to facilitate an expeditious transition process, the government should enact laws that clarify the rules regarding compensation in lieu of restitution in the northern territory. Specifically, only those properties that were seized by the Northern regime under the 1946 Law on Land Reform until the collectivization of its farming industry in 1958 should be compensated. Compensation should be offered to owners of properties in lieu of restitution on whose properties buildings or other economic infrastructures were erected. Those properties that belong to Japanese occupants prior to the 1945 Liberation, as well as the land confiscated from landlords and absentee landowners, should not receive compensation, as precedents have been already set in SK's land reform in the 1950's and 60 's. In essence, although property rights should be acknowledged to reinforce the importance of economic institutions in a market economy, it should not hinder the development of a new economic structure. This should facilitate the coalition building process under which consensus building would start in favor of reform in NK.

\section{Privatization and the Market Structure}

The SOE sector is highly integrated both horizontally and vertically (Kang and Lee, 1993) through 'associated enterprises', a form of conglomerates that are vertically and/or horizontally

6) However, restitution takes time to transfer properties back to original owners. integrated similar to that used by the former East Germany Kombinaten (Andreff, 1989). A brief survey by KOTRA (1995) indicates that heavy industries which produced over $74 \%$ of all manufacturing output in 1990, including steel making, fertilizer, petro-chemical, and other metal industries, all have highly concentrated industrial structures. Heavy industries are dominated by two or three large SOEs which are vertically and/or horizontally integrated. This is in response to information asymmetry and raw material hoarding problems coupled with the implementation of an independent accounting system' that created autonomous profitcenters. This raises concerns over horizontal collusion and vertical foreclosure of supplier and buyer markets (Tirole, 1991).

Since privatization of SOEs in NK requires substantial restructuring at the industry level, many have raised the appropriate role of the State.7) Some economists including Tirole (1991) suggest that measures aimed at promoting "competitionoriented-restructuring" such as trade liberalization and anti- trust legislation will not be sufficient to create appropriate market structures. In other words, conventional reform processes are susceptible to pressure groups who argue for a continuation of state subsidies and protection from foreign competition, which implies that more fundamental reform of SOE sector should be initiated by the state .

Instead of the government taking a lead role to restructure NK's SOE sector, it should allow the market to decide the appropriate structure. Except in instances where the sales of northern SOE will pose serious anti-monopolistic problems, the government should not restrict potential buyers in the bidding process. This is because state-led efficiencyoriented restructuring measures will only introduce

7) This is because ex-ante regulation of mergers or excessive vertical or horizontal is easier than ex-post regulation through break-up of large firms (Vickcrs and Yarrow, 1990). 
further rigidities in the economy.8) In instances where a large outlay of capital is required, multinationals and chaebols should actively participate in the privatization process. The government's role, then, is to carry out the divestiture process expeditiously through a fair and equitable system. The ultimate goal of the privatization program should be focused on developing an efficient market-based economy through a smooth transition process.

\section{Privatization Agency: Treuhand as a Model}

Because the privatization process requires coordination among different ministries, there is a need for a central agency to handle all divestiture plans. By creating a holding company-type of privatization agency, it can deal with the uncertainties of a transition economy more effectively. Specifically, it can stabilize the ownership of SOEs to avoid spontaneous privatization and further deterioration of SOEs. Although small to medium size firms can be readily privatized without implications to industrial concentration problems, large monopolistic SOEs, especially those in heavy and utilities industries, may take time to sell and thus require to be broken up or restructured.

Lee (1995) proposed a scheme under which the SK government would combine sales and give away privatization plans under the Treuhandanstalt type of privatization agency. Under the proposal, control of SOEs and cash flow rights to all North Korean SOEs would be transferred to an agency. The agency would then sell the controlling rights of SOEs to appropriate private parties through public auctions while a minority of these shares will be distributed among North Korean citizens. This would be done through a voucher scheme where all households would receive vouchers as claims

8) Economic rigidities in terms of conditions attached in the sale of SOEs like those seen in EEFSU. In particular, the Treuhand in Germany often attached conditions for future investments and labor policies. against private trust funds. Vouchers would be exchanged for special mutual funds, which in turn could be used to purchase the remaining shares in privatized firms held by the privatization agency. Three markets will emerge as a result: (1) A market for corporate control of NK's SOEs; (2) A market for vouchers; and (3) A market for shares held by private agencies.

The Treuhand concept used in Germany provides a useful lesson for Korea. Treuhand was basically a fiduciary holding company under the supervision of the German Parliament. In June 1990, the Parliament enacted "The Law on the Privatization and Reorganization of National Property" which declared that the "transfer, break-up and privatization of state economic monopolies into decentralized, private owned economic units is the decisive prerequisite for a switch from a planned economy to a market economy." Thus, Treuhand's mandate was to nationalize and then divest as quickly as possible in order to maintain uninterrupted business operations. As a result of the Act, Treuhand became the sole owner of 12,370 large former Eastern German SOEs, ranging from coal mines to corner bakery shops. Although privatization was clearly given a priority, restructuring was considered when appropriate. The credible threat of bankruptcy and liquidation of non-viable and non-performing business units quickly erased the soft budget constraints of those firms under Treuhand's control. However, only $7 \%$ of all former GDR's SOEs were eventually liquidated, as opposed to $70 \%$ initially estimated by students of reform economies (Hind, 1990).

Throughout the privatization process, West Germany sought to establish clear guidelines to "limit to its commitments to preserve an 'industrial core'." Only firms with high probabilities of surviving in the market were given state subsidies for a limited time. But, as it turned out, this idea of the agency being 'hard' was very naive from the beginning. Bowing to political pressures, Treuhand 
had to compromise its mandate with other political and social considerations, especially on the labor front. Political interventions and labor disputes arising from cutting subsidies proved to be obstacles to the privatization plan (The Economist (March 21, 1992). This is why The Economist (March 21, 1992) depicted the German privatization approach and the Treuhand concept as "a rich uncle's solution." Aside from subsidies provided by West Germany, an amount equivalent to roughly half of the East's pre-union GDP was transferred to keep failing enterprises afloat. As of January 1996, all but one hundred SOEs have been sold or liquidated, while most large companies have been sold to West German firms (The Economist, February $13,1996)$. In terms of costs, $60 \%$ of the four million workers Treuhand once employed were laid-off. In addition, only one tenth of the estimated privatization proceeds of DM 600 billion $(\$ 370$ billion) materialized while the state incurred a debt of DM 270 billion. 9)

The cost of saving jobs in SOEs was greater than other policy options of pursuing training and relocation programs. Carlin and Mayer (1992) argued that the former benefit outweigh the latter costs. More importantly, it was reported that over $91 \%$ of the East Germans disapproved the Treuhand's policies, thereby alienating the population in the East. However, 1.5 million jobs and DM 207 billion worth of investments have already been promised by private investors.

Korean policy makers seem to have embraced the concept of a central privatization agency (Lee, 1995). However, the question of whether to pursue a more radical privatization process or a more gradual privatization and restructuring process has yet to be resolved. In addition, the task of pursuing other social and industrial policies aimed at providing social safety nets require further exami-

9) It had to assume a lot of financial and environmental liabilities in order to sell these SOEs. nation. It will face society- wide pressures to assume responsibility for social and economic hardships. It is important to note that the overriding responsibility of the agency is to privitize SOEs rather than take on other industrial and social policies. In addition, the cost under more gradual processes are more prohibitive in the long run due to the state's soft budget constraints and continuing state subsidies. As Dornbush and Wolf (1992) argue, "wrapping social policy and industrial policies together in one institution, the Treuhand runs the risk of being ineffective." In other words, concern for other the social and economic policies, which should largely be left to the working of the market institutions, has the potential of making the primary task of privatization ineffective. ${ }^{10}$ )

We argue further that post-privatization performance of SOEs depends on private sector investments. Although efficiency-oriented restructuring measures should be left to the new owners, the state should encourage those owners to invest through various credit and financial policies. If subsidies are needed for political or economic reasons, only viable enterprises should be granted a one-time capital injection, which can be used to boost competitiveness through hiring new employees or making new investments.

Pressure from public and SOE employees to continue government involvement will be strong in view of the fact that state subsidies and other social welfare benefits will have to be slashed substantially. The State will be also be tempted to intervene in the management of SOEs. To avoid the capture of the state's decision making during the transition period, the independent nature of the privatization

10) However, Lee (1995) is not clear whether the agency should act the dual role of a privatization agency and a trust fund. He also fails to mention whether this 'independent agency' should be made answerable to any executive or legislative agency. This makes a big difference as legislatures are more easily influenced by the public consensus than the executive branch. 
agency should be emphasized. To this end, the agency should report to the executive branch of the government since the legislative branch is likely to act more opportunistically. In terms of the organizational structure, the agency should consist of three divisions: the first dealing with natural monopolies, the second dealing with small to medium size firms that are in naturally competitive sectors, and the last dealing with firms that require industrial restructuring. This should quicken the pace of the divestiture process as viable enterprises sold while more quickly than national utilities and large SOEs. The question over the exact number of holding companies required to encourage healthy competition is not clear. This would require more information than is currently available on the NK economy and its SOE sector. Having numerous holding companies should also open up markets for firms and access to more information regarding the operation of SOEs.

In addition, we note that the success of implementing privatization process depends on the unification policy pursued, as well as the initial conditions of the NK's economy. The currency convertibility and the rate at which the NK currency is made convertible to SK Won, as we have seen in the case of the German's botched attempt at currency conversion, would largely determine the fate of a large number of SOEs in NK.

\section{Corporatization}

Corporatization is a term that involves establishing corporate charts and providing share issuance information that includes numbers, types, initial flotation prices, and initial valuation. In addition, detailed valuation, lists of assets, liabilities, and assessment of environmental clean-ups will have a significant impact on the speed with which they can be transformed into the private sector. It should be noted that all corporatized SOEs should be in the form of an open joint stock company in order to allow active trading in the both primary and secondary markets. The privatization agency should provide a pipeline of corporatized SOEs by standardizing the process with guidelines, regulations, and standard forms to complete with the help of outside accounting firms and consultants.

The government should also consider creating supervisory boards, mainly consisting of executives and technicians on loan from SK enterprises, in each SOE. This would allow northern SOEs to tap into the resources of the South during the transition period. In this regard, the agency should also join forces with industry leaders and industry associations to bring the private sector into the arena. Although the state is likely to play a key role, accounting firms, investment banks, and commercial banks should be encouraged to actively participate in the process. The important role of banking institutions, as advocated in Aoki and Kim (1995), should not be taken lightly given massive financing required in NK.

In terms of creating a viable and effective corporate governance structure, Aoki (1995) warns that insiders have a tendency to have control in transition economies and explains why the model of shareholder sovereignty may be an effective solution to that problem. He argues that since institutional development of internal organizations in transition economies remains uncertain, an evolutionary approach to corporate governance design is preferable. Roland (1995) also argues that massive giveaways or re-distribution of corporate assets may result in either insider control (Lipton and Sachs, 1990) or the concentration of economic power (Webster, 1993), which may consequently lead to "the deterrence of economically viable restructuring and de facto re-nationalization." For this reason, Roland favors a gradual approach in reforming the corporate governance structure in transition economies. The following basic problems are similar: "enterprise reform, which requires the imposition of bottom-line discipline, definition and change of ownership, and reform of 
management" (Fischer and Gelb, 1991).

\section{Broad-Based Ownership Programs}

In countries where the move towards privatization has been hampered by political and social constraints, broad-based ownership programs have proven to be effective (Bell, 1995). Countries ranging from Czechoslovakia to Zambia have utilized broad-based ownership programs as a participatory tool to privatize SOEs and to answer those who object to 'selling the family silver' (World Bank, 1995). In comparison to traditional privatization techniques, broad-based schemes, including voucher-based programs, collective investment programs, and public offerings, offer three distinct advantages (Bell, 1995): political acceptability, opportunities to target income redistribution, and capital market development. In this section, we will examine two techniques in detail: the voucher scheme and the employee stock ownership plan (ESOP).

\section{Voucher Scheme}

Although efficiency considerations are likely to shape the ideal course of privatization programs in NK, the participation of the Northerners and ensuring a general principle of fairness are also critical. In general, economic hardship combined with a series of structural adjustment programs will generate political opposition to mass privatization schemes. If Northerners view privatization simply as a transfer of assets to the wealthy South, they will distrust the newly created market institution and economic system in general. Also, the privatization process entails short-term contractions in economies and a fall in real purchasing power. For these reasons, we argue that voucher schemes be incorporated into mass privatization plans with sufficient incentives for the public to get involved (Tirole, 1991; Hind, 1991).

Voucher programs involve the distribution of vouchers (coupons) to a selected population that can be exchanged for shares in individual SOEs, investment funds, or other financial intermediaries who take on the role of mutual funds in managing their investments. The advantages of using financial intermediaries to act as fund managers include: (1) Allowing less-experienced voucher-holders to diversify investment risks; (2) Enabling financial intermediaries to act as core investors in privatized firms to encourage restructuring and reorganization; and (3) Contributing to the development of capital markets.

Another option is the creation of privatized funds where holders collectively become the owners of funds comprised of SOE shares. Public offerings encourage widespread shareholdings of privatized SOEs. Often, financial intermediaries or government administrative systems are utilized to encourage the broad-based scheme, which imply that a well-structured bureaucratic administrative system or a well-functioning capital markets are in place. People's Stock Ownership Program (Kim, 1996) used in SK represents a variation of such schemes where low to middle income households were offered deep discounts in the sale of government's blue-chip companies, including Korea Electric Power Corporation (KEPCO) and Pohang Iron and Steel Company (POSCO).

We argue that SK should adopt the Czech and Slovakian voucher schemes where North Korean citizens receive vouchers which can either be directly used to convert into shares through public auctions or placed with investment funds. The voucher scheme would also allow North Koreans to start with some forced savings and to ensure a fair and equitable distribution of NK's wealth among the population at large. This also has the advantage of giving more options to North Koreans in finding ways to invest their savings-either through direct investments in the primary market or through fund managers. 


\section{Employee Stock Ownership Program (ESOP)}

The advantage of being an insider during the initial phase of economic and social reform relates to the expropriation of assets of SOEs. This phenomenon of 'spontaneous privatization' is more likely to spread during the initial reform phase when the administrative apparatus of the state collapses. This leaves managers or members of the enterprise management committees as de facto and at times de jure owners of the SOEs. In order to avoid spontaneous privatization and to gain the support of managers, which is critical to the success of any MPP, some argued that they should be included in the ownership (Blasi, 1994).

Involving insiders, however, has grave consequences on the initial economic reform process and equity structure. Bocko, Shleifer, and Vishny (1993) found that low valuations of Russian assets are a result of a weakened position of outsiders with respect to insiders and the state. Although liquid voucher market would allow core investors to monitor corporate management, initial conditions often determine the success of MPPs. Thus, the question is whether to employ the Polish model which gave away as much as $15 \%$ of shares issued by new joint-stock companies to insiders, or to follow the Czech and Slovak model where branch ministries were successful at retaining control of the privatization process chose not to give employees preferential treatments.

Although the most desirable privatization scheme will likely become apparent as the Korean peninsula moves closer to unification, the concentration of ownership in the hands of a few insiders is bad news for corporate governance, since managers have incentive to abuse the rights of minority shareholders (Webster et al., 1994). In addition, managers are much-hated communist members who may become the target of a 'witch hunt,' which may further complicate the process. Although linking and aligning managerial incentives with that of the principal is important, the state should play a key role in balancing objectives by ensuring an equitable distribution of shares and monitoring performance.

\section{CONCLUSIONS AND POLICY IMPLICATIONS}

We argue that it is critical for the privatization agency in Korea to emphasize its main objectives, which should include the following:

- To expedite the sales and liquidation of all SOEs in NK;

- To identify enterprises or part of enterprises that can be made viable:

- To repackage their assets to more attractive bundles;

- To find buyers that are willing to make firm commitments to retain workers and invest more.

The effectiveness of MPP depends on the political stability and sustainability of broad reform policies required in NK's economy. The issue is complicated by the likelihood of massive migration from NK to SK once the NK economy collapses and the border opens. ${ }^{11}$ ) The desire of the SK government and its political elites to maintain the political and economic status quo and prevent the massive inflow of North Koreans has largely shaped the gradual reform policies in recent years (Cho and Lee, 1995).

As seen in EEFSU, mass privatization is an intense political process that requires strong leadership from the top as well as bottom-up political support from workers, managers, and the population at large. Given that NK's productivity is likely to be in less than the East Germans, which was long touted as the best among communist

11) It would not be politically feasible to close the borders once the two countries are united, as seen in the case of the collapse of the Berlin Wall. 
nations, ${ }^{12)}$ simultaneous restructuring and reform programs are essential. This makes privatization all the more critical.

The primary goal of MPP should be to create the conditions for a North Korean market economy, which is best achieved by selling off SOEs as quickly as possible. Other economic and social concerns should not deter the government should tackle the main problem: the conversion of the highly inefficient and unproductive industrial sectors through a central privatization agency to a marketbased economy. This is because a gradual process where the state attempts to revive SOEs through investment and governance reform programs will lead to the continuation of the soft budget conditions. Although restructuring and investment programs should be managed by new owners, the State should provide a conducive environment under which these former-SOEs can flourish. In addition, the State should not be distracted by the call of nationalism to discourage the FDI during the privatization process. According to Saber's findings (1994), the active participation of foreign investors in the privatization process also initiate further investments during the post-privatization process, which means that the SK government must actively encourage foreign investment. There are other requisites for successful privatization: transparent and well-educated process (Donaldson, 1996).

It is inevitable that the process will require massive institutional support from SK's business and financial communities. Finally, the success of privatization plans in Mongolia and Hungary and the explosive growth of small-to-medium size private enterprises in numerous transition economies suggest that the key to the long-run transformation in NK is in developing the private sector rather than privatizing it. This implies that privatization of

12) Evidenced by the demise of East Germany's machine tool industry after unification, a jewel in the crown of Soviet-style economies, it is unlikely that any NK industries will be competitive.
SOEs should be distinguished from employment creation and social policies. Any departure from its original mission will likely blur the whole picture. In sum, it is important to establish an economic reform agenda early; otherwise, the window of opportunity available in reforming transition economies may be lost, which will only make the reform process much harder to implement in future dates.

\section{Bibliography}

Aslund, Anders, and Boone, Peter and Johnson, Simon. 1996. How to Stabilize: Lessons from

Post-Communist Countries, Forthcoming in

Brookings Papers on Economic Activity.

Averch, H. and Johnson, L. 1962. Behavior of the

Firm under Regulatory constraint. American

Economic Review. 52.

Balcerowicz, Leszek and Gelb, J. 1994. Polish

Economic Reform, 1981 - 1988: An Overview. mimeo. United Nations.

Bank of Korea. 1996. The estimation of North Korean GNP. Seoul. Korea.

Bank of Korea. 1996. Annual Statistics. Seoul. Korea.

Blanchard, Oliver and Richard, Layard. 1990. How to Privatize, In H. Siebert(ed.) The Transformation of Socialist Economies: Symposium 1991. Tubingen: J. C. B. Mohr.

Campbell, Robcrt W. 1992. The Soviet-Type Economies: Performance and Evolution. Boston: Houghton Mifflin.

Chang, H. J. and Singh, A. 1993. Public Enterprises in Developing Countries and Economic Efficiency. UNCTAD Review. 3.

Cho, Lee-Jay and Kim, Yoon-Hyung. 1995. Economic Systems in South and North Korea: The Agenda for Economic integration. Korea Development Institute.

Chong, B. H. 1990. Economic Concentration and Anti-Monopoly Policies. Mimeograph. Hono- 
lulu, East-West Center.

Desai, Padma. 1986. The Soviet Economy: Efficiency, Technical Change and Growth Retardation. Oxford: Basil Blackwell.

Eberstadt, N. and Banister, J. 1992a. The Population of North Korea. Berkeley: Institute of East Asian Studies, University of California.

Eberstadt, Nicholas and Banister, Judith. 1992b.

Divided Korea: Demographic and Socioeconomic Issues for Reunification. Population and Development Review. 18(3).

Fischer, Stanley. 1990. Economic Reform in the USSR and the Role of Aid. Brookings Papers on Economic Activity. 2: 289 301. Washington D.C.: Brookings Institute.

Frydman, Roman and Rapaczynski, Andrzej. 1991. Markets and Institutions in Large Scale Privatizations: An Approach to Economic and Social Transformations in Eastern Europe. New York University.

Gelb, Alan H. and Gary, Cheryl W. 1991. The Transformation of Economies in Central and Eastern Europe: Issues, Progress, and Prospects. Washington, D. C.: The World BankIMF Working Paper.

Heitger, B. and Waverman, L. 1993. German Unification and the International Economy. University of Toronto.

Jeong, Kap-Young. 1992. The North Korean Economy. Korea and World Affairs. Spring.

KDI. 1991. A Basic Idea for Improving the Economic Relationship between North and South Korea Seoul.

KDI. 1996. North Korean Economy. Seoul.

Kim, Il-Sung. 1971. Selected Works. Pyongyang: Foreign Languages Publishing House.

Kim, Jun Ki. 1996. Korean SOE sector Reform and Privatization: Changing Managerial Incentive and the Transfer of Control Rights. Korean Journal of Policy Studies. 11: 47 71. Seoul. Korea.

Koo, B. H. and Jo, O. 1995. Comparative Analysis of the North and South Korean Economics in Lee-Jay Cho and Yoon-Hyung Kim (ed.). Economic systems in South and North Korea. KDI, Seoul.

Koo, Bon-Hak. 1992. Political Economy of Self Reliance. Seoul.

Korea Trade Promotion Corporation. 1993. North Korea Investment Manual. Seoul.

Kornai, J. 1979. Economics of Shortage. Amsterdam, North-Holland.

Kornai, J. 1992. The Road to Freedom. New York, Norton.

Lardy, Nicholas. 1986. Overview: Agricultural Reform and the Rural Economy. mimeo. U.S. Congress.

Lee, H. 1990. The August Third Program of North Korea: A Partial Rollback of Central Planning. Korean Observer. 24(4). Seoul

Lieberman, Ira and John Nellis. 1995. Creating Private Enterprises and Efficient Markets World Bank.

Lipton, David and Sachs, Jeffrey. 1991. A Program for Economic Sovereignty and Restructuring of Slovenia: A Proposed Policy Framework.

I ipton, David and Sachs, Jeffrey. 1990. Creating a Market Economy in Eastern Europe: The Case of Poland. Brookings Papers on Economic Activity. 1: $75 \sim 113$.

McKinnon, Ronald. 1993. The Order of Economic Liberalization: Financial Control in the Transition to a Market Economy. Baltimore, Johns Hopkins University Press.

Merill, John. 1991. North Korea's Halting Efforts at Economic Reform In Chong-sik Lee and Se-Hee Yoo(eds.). North Korea in Transition. Korea Research Monograph 16 Center for Korean Studies. University of California at Berkeley.

Moon, P. Y. 1995. The Agricultural Economy of North Korea: Parallel Study of the North Korean and Chinese Sucialist Economies. Unpublished mimeograph. East-West Center, 
Honolulu.

Moon. P. Y. and B. S. Kang. 1989. Trade Exchange Rate and Agricultural Pricing Policies in the Republic of Korea

Oh, Kwan-Chi. 1990. The Development Process and Performance of Economic Planning, In Tae-Wook Lee(ed.) The North Korean Economy. Seoul.

Perkins, Dwight. 1988. Reforming China's Economic System. Journal of Economic Literature. 26(2): $601 \sim 45$. June.

Perkins, Dwight and Michael, Roemer. 1991. Reforming Economic Systems in Developing Nations. Cambridge Harvard University Press.

Sachs, Jeffrey D. 1995. Reforms in Eastern Europe and the Former Soviet Union in Light of the East Asian Experiences, Prepared for the NBER-TCER-CEPR Trilateral Conference on
Transition from Socialist Economies. January 6 7. Tokyo.

Sachs, Jeffrey D. and Wing Thye Woo. 1995. Structural factors in the Economic Transition of China, Eastern Europe, and the Former Soviet Union. Economic Policy. 18. April.

Singh, A. 1992. Close vs Strategic Integration with the World Economy. mimeo. University of Cambridge.

Stern, J. J., Kim, J., Perkins, Dwight H. and Yoo, J. 1995. Industrialization and the State: The Korean Heavy and Chemical Industry Drive. HIID.

Yeon, Ha-Cheong. 1990. Economic Management and Policy Determination in North Korea, In Tae-Wook Lee(ed.) The North Korean Economy. Seoul: Eul-Yoo Moonhwa. 